\title{
POTENSI DAYA DARI SOLAR CELL TERPASANG SESUAI DENGAN POLA ATAP RUMAH BERBASIS ARSITEKTUR BALI
}

\author{
I Nyoman Apriana Arta Putra ${ }^{1}$, Wayan Arta Wijaya ${ }^{2}$, I.G.N Janardana ${ }^{3}$ \\ Program Studi Teknik Elektro, Fakultas Teknik, Universitas Udayana \\ Email: aprianaarta44@yahoo.com ${ }^{1}$, artawijaya@ee.unud.ac.id ${ }^{2}$, janardana@unud.ac.id ${ }^{3}$
}

\begin{abstract}
ABSTRAK
Penelitian ini dilakukan untuk mengetetahui besar potensi daya yang didapat pada rumah dengan pola atap berasitektur Bali jika dikembangkan dengan sumber energi terbarukan. Energi surya sebagai sumber energi terbarukan mempunyai potensi yang sangat besar, khususnya di Indonesia. Pola atap rumah berbasis arsitektur Bali mempunyai 4 bidang, sisi sebelah utara dan selatan berbentuk trapesium dan sisi sebelah timur dan barat berbentuk segitiga dengan sudut kemiringan atap $35^{\circ}$. Salah satu bangunan tradisional Bali adalah Bale Sari, yang menjadi study kasus dengan luas $32,64 \mathrm{~m}^{2}$, panjang $6,40 \mathrm{~m}$ dan lebar 5,10m. Atap Bale Sari berpola limas, setiap sisinya mempunyai panjang dan lebar yang sama. Metode yang dilakukan pada penelitian ini dengan perhitungan manual untuk mencari potensi daya maksimalnya.Jumlah seluruh panel surya yang digunakan adalah 234 buah. Dengan jumlah ini, didapatkan hasil potensi terbaiknya pada sisi bagian selatan, dengan rata-rata daya yang didapat sebesar 667,67 Watt. Hasil tersebut didapatkan ketika matahari berada pada titik pemanasan maksimal atau tepatnya saat cuaca cerah. Hasil analisis potensi daya rata-rata yang didapat solar cell terpasang pada atap rumah berarsitektur Bali sebesar 1.935,49 Watt.
\end{abstract}

Kata Kunci : Arsitektur Bali, Bale Sari, Panel Surya, Potensi Daya.

\section{ABSTRACT}

This study was conducted to determine the potential power obtained at home with the Balinese roof pattern when developed with renewable energy sources. Solar energy as a source of renewable energy has enormous potential, especially in Indonesia. Balinese architecturebased roof pattern has 4 fields, the north and south side are trapezoidal and the east and west sides are triangular with $35^{\circ}$ roof inclination angle. One of Bali's traditional buildings is Bale Sari, which is a case study with an area of $32.64 \mathrm{~m} 2$, length $6.40 \mathrm{~m}$ and width $5.10 \mathrm{~m}$. Bale Sari's roof has a pyramid pattern, each side having the same length and width. Methods performed in this study with manual calculations to find the potential maximum power. The total number of solar panels used is 234 pieces. With this amount, obtained the best potential results on the southern side, with an average power gained of 667.67 Watt. The results are obtained when the sun is at a maximum warming point or precisely when the weather is sunny. The result of the average power potential analysis obtained by solar cell installed on the roof of the Balinese architecture house is $1,935.49$ Watt.

\section{Keywords : Architectur Bali, Bale Sari, Solar Cell, Power Potential}

Dengan jumlah ini, didapatkan hasil potensi terbaiknya pada sisi bagian selatan, dengan rata-rata daya yang didapat sebesar 667,67 Watt. Hasil tersebut didapatkan ketika matahari berada pada titik pemanasan maksimal atau tepatnya saat cuaca cerah. Hasil analisis potensi daya rata-rata yang didapat solar cell terpasang pada atap rumah berarsitektur Bali sebesar 1.935,49 Watt. yang menjadi study kasus mempunyai luas $32,64 \mathrm{~m}^{2}$ dengan panjang $6,40 \mathrm{~m}$ dan lebar $5,10 \mathrm{~m}$, atap berpola limas. Setiap sisi Bale Sari mempunyai panjang dan lebar yang sama. Zaman sekarang rumah dengan pola atap berarsitektur Bali sudah jarang ditempati dan bahkan cenderung dilupakan. Masyarakat 
pada umumnya lebih cenderung beralih menggunakan rumah berasitektur modern untuk di tempati karena efisiensi dan kesederhanaan. Sumber energi yang tepat untuk dikembangkan pada rumah berasitektur Bali adalah sumber energi surya, karena energi surya merupakan energi alternatif yang murah dan mudah didapatkan untuk memenuhi kebutuhan energi listrik.

Penelitian ini dilakukan untuk mendapatkan potensi daya maksimal pada rumah berasitektur Bali dan bertujuan memodernisasi arsitektur Bali agar tidak tergerus oleh zaman, dan tanpa mengubah estetika dari pola atap rumah berasitektur Bali. [1][2]

\section{PENDAHULUAN}

Pola atap rumah berbasis arsitektur Bali, mempunyai 4 bidang, yaitu sisi sebelah utara dan selatan berbentuk trapesium dan sisi sebelah timur dan barat berbentuk segitiga dengan sudut kemiringan atap $35^{\circ}$. Bale Sari yang menjadi study kasus mempunyai luas $32,64 \mathrm{~m}^{2}$ dengan panjang $6,40 \mathrm{~m}$ dan lebar $5,10 \mathrm{~m}$, atap berpola limas. Setiap sisi Bale Sari mempunyai panjang dan lebar yang sama. Zaman sekarang rumah dengan pola atap berarsitektur Bali sudah jarang ditempati dan bahkan cenderung dilupakan. Masyarakat pada umumnya lebih cenderung beralih menggunakan rumah berasitektur modern untuk di tempati karena efisiensi dan kesederhanaan. Sumber energi yang tepat untuk dikembangkan pada rumah berasitektur Bali adalah sumber energi surya, karena energi surya merupakan energi alternatif yang murah dan mudah didapatkan untuk memenuhi kebutuhan energi listrik.

Penelitian ini dilakukan untuk mendapatkan potensi daya maksimal pada rumah berasitektur Bali dan bertujuan memodernisasi arsitektur Bali agar tidak tergerus oleh zaman, dan tanpa mengubah estetika dari pola atap rumah berasitektur Bali. [1][2]

\section{KAJIAN PUSTAKA}

\subsection{Atap Rumah Berasitektur Bali}

Atap rumah berasitektur Bali mempunyai ciri khas berpola atap limas dengan ditopang beberapa pilar yang menjadikan atap rumah berasitektur Bali terlihat elegan dan mewah.

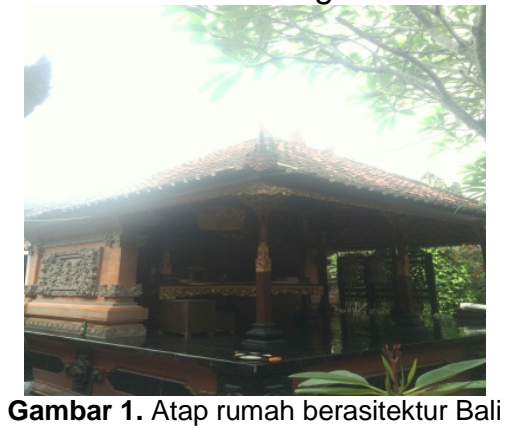

Atap rumah berasitektur Bali mempunyai dua sisi bagian yang berbeda, seperti pada rumah berasitektur Bali pada Gambar 1. Gambar 1 merupakan studi kasus pada penelitian ini mempunyai dua bagian yang berbeda, pada sisi utara dan selatan mempunyai pola bentuk trapesium, pada sisi bagian barat dan timur berpola segitiga. Untuk menghitung luas dari pola atap

tersebut digunakan rumus (1) dan (2), sebagai berikut :

$$
\begin{aligned}
& \text { Luas } \Delta=\frac{1}{2} x(A x T) \\
& \begin{aligned}
\text { Luas Trapesium } & =\frac{\text { jumlah sisi } x \text { tinggi }}{2} \\
& =\frac{(A B+C D) \text { tinggi }}{2}(2)
\end{aligned}
\end{aligned}
$$

\subsection{Energi Surya}

Energi surya merupakan energi terbarukan yang mempunyai sumber yang sangat besar dan sangat penting dalam memenuhi kebutuhan energi. Intensitas energi surya mencapai puncaknya pada siang hari. Indonesia mempunyai intensitas radiasi matahari yang sangat baik, yang ditunjukkan pada Tabel 1. [3][4]

\begin{tabular}{|c|c|c|c|c|}
\hline Propinsi & Lokasi & $\begin{array}{c}\text { Tahun } \\
\text { pengukur } \\
\text { an }\end{array}$ & $\begin{array}{c}\text { Posisi } \\
\text { geografi } \\
\mathrm{s}\end{array}$ & $\begin{array}{c}\text { Intensit } \\
\text { as } \\
\text { radiasi } \\
\left(\mathrm{Wh} / \mathrm{m}^{2}\right. \\
\text { ) }\end{array}$ \\
\hline NAD & Pidie & 1990 & $\begin{array}{l}4^{\circ} 15^{\prime} \\
\text { LS : } \\
96^{\circ} 52^{\prime} \mathrm{B} \\
\mathrm{T}\end{array}$ & 4.097 \\
\hline $\begin{array}{l}\text { Sum } \\
\text { Sel }\end{array}$ & $\begin{array}{l}\text { Ogan } \\
\text { komerin } \\
\text { g Ulu }\end{array}$ & $\begin{array}{l}1979- \\
1981\end{array}$ & $\begin{array}{l}3^{\circ} 10^{\prime} \\
\text { LS : } \\
104^{\circ} 42^{\prime} \\
\text { BT }\end{array}$ & 4.951 \\
\hline
\end{tabular}

Tabel 1. Pengukuran Intensitas Radiasi Matahari di Indonesia 


\begin{tabular}{|c|c|c|c|c|}
\hline $\begin{array}{l}\text { Lampun } \\
\mathrm{g}\end{array}$ & $\begin{array}{l}\text { Kab. } \\
\text { Lampun } \\
\text { g selatan }\end{array}$ & $\begin{array}{l}1972- \\
1979\end{array}$ & $\begin{array}{l}4^{\circ} 28^{\prime} \\
\text { LS : } \\
105^{\circ} 48^{\prime} \\
\text { BT }\end{array}$ & 5.234 \\
\hline $\begin{array}{l}\text { DKI } \\
\text { Jakarta }\end{array}$ & $\begin{array}{l}\text { Jakarta } \\
\text { Utara }\end{array}$ & $\begin{array}{l}1965- \\
1981\end{array}$ & $\begin{array}{l}6^{\circ} 11^{\prime} \\
\text { LS : } \\
106^{\circ} 05^{\prime} \\
\text { BT }\end{array}$ & 4.187 \\
\hline \multirow[t]{2}{*}{ Banten } & $\begin{array}{l}\text { Tangera } \\
\text { ng }\end{array}$ & 1980 & $\begin{array}{l}6^{\circ} 07^{\prime} \\
\text { LS : } \\
106^{\circ} 30^{\prime} \\
\text { BT }\end{array}$ & 4.324 \\
\hline & Lebak & $\begin{array}{l}1991- \\
1995\end{array}$ & $\begin{array}{l}6^{\circ} 11^{\prime} \\
\text { LS : } \\
106^{\circ} 30^{\prime} \\
\text { BT }\end{array}$ & 4.446 \\
\hline \multirow[t]{2}{*}{$\begin{array}{l}\text { Jawa } \\
\text { Barat }\end{array}$} & Bogor & 1980 & $\begin{array}{l}6^{\circ} 11^{\prime} \\
\text { LS : } \\
106^{\circ} 39^{\prime} \\
\text { BT }\end{array}$ & 2.558 \\
\hline & Bandung & 1980 & $\begin{array}{l}6^{\circ} 56^{\prime} \\
\text { LS : } \\
107^{\circ} 38^{\prime} \\
\text { BT }\end{array}$ & 4.149 \\
\hline $\begin{array}{l}\text { Jawa } \\
\text { tengah }\end{array}$ & $\begin{array}{l}\text { Semaran } \\
\mathrm{g}\end{array}$ & $\begin{array}{l}1979- \\
1981\end{array}$ & $\begin{array}{l}6^{\circ} 59^{\prime} \\
\text { LS : } \\
110^{\circ} 23^{\prime} \\
\text { BT }\end{array}$ & 5.488 \\
\hline $\begin{array}{l}\text { Jogjaka } \\
\text { rta }\end{array}$ & $\begin{array}{l}\text { Yogyaka } \\
\text { rta }\end{array}$ & 1980 & $\begin{array}{l}7^{\circ} 37^{\prime} \\
\text { LS : } \\
110^{\circ} 01^{\prime} \\
\text { BT }\end{array}$ & 4.500 \\
\hline $\begin{array}{l}\text { Jawa } \\
\text { Timur }\end{array}$ & Pacitan & 1980 & $\begin{array}{l}7^{\circ} 18^{\prime} \\
\text { LS : } \\
112^{\circ} 42^{\prime} \\
\text { BT }\end{array}$ & 4.300 \\
\hline Kal Bar & $\begin{array}{l}\text { Pontiana } \\
\mathrm{k}\end{array}$ & $\begin{array}{l}\text { 1991- } \\
1993\end{array}$ & $\begin{array}{l}4^{\circ} 36^{\prime} \\
\text { LS : } \\
9^{\circ} 11^{\prime} B T\end{array}$ & 4.552 \\
\hline Kal Tim & $\begin{array}{l}\text { Kabupat } \\
\text { en Berau }\end{array}$ & $\begin{array}{l}1991- \\
1995\end{array}$ & $\begin{array}{l}0^{\circ} 32^{\prime} \\
\text { LU : } \\
117^{\circ} 52^{\prime} \\
\text { BT }\end{array}$ & 4.172 \\
\hline Kal Sel & $\begin{array}{l}\text { Kota } \\
\text { Baru }\end{array}$ & $\begin{array}{l}1979- \\
1981\end{array}$ & $\begin{array}{l}3^{\circ} 27^{\prime} \\
\mathrm{LU}: \\
114^{\circ} 50^{\prime} \\
\text { BT }\end{array}$ & 4.796 \\
\hline $\begin{array}{l}\text { Sul } \\
\text { Teng }\end{array}$ & $\begin{array}{l}\text { Donggal } \\
\mathrm{a}\end{array}$ & $\begin{array}{l}\text { 1991- } \\
1994\end{array}$ & $\begin{array}{l}0^{\circ} 57^{\prime} \\
\text { LS : } \\
120^{\circ} 0^{\prime} \mathrm{B} \\
\mathrm{T}\end{array}$ & 5.512 \\
\hline Papua & $\begin{array}{l}\text { Ja } \\
\text { yapura }\end{array}$ & $\begin{array}{l}1992- \\
1994\end{array}$ & $\begin{array}{l}8^{\circ} 37^{\prime} \\
\text { LS : } \\
112^{\circ} 12^{\prime} \\
\text { BT }\end{array}$ & 5.720 \\
\hline Bali & $\begin{array}{l}\text { Denpasa } \\
r\end{array}$ & $\begin{array}{l}1977- \\
1979\end{array}$ & $\begin{array}{l}8^{\circ} 40^{\prime} \\
\text { LS : } \\
115^{\circ} 13^{\prime} \\
\text { BT }\end{array}$ & 5.263 \\
\hline NTB & Kabupat & 1991- & $9^{\circ} 37^{\prime}$ & 5.747 \\
\hline
\end{tabular}

\begin{tabular}{|c|c|c|c|c|}
\hline & $\begin{array}{l}\text { en } \\
\text { Sumbaw } \\
\text { a }\end{array}$ & 1995 & $\begin{array}{l}\text { LS : } \\
120^{\circ} 16^{\prime} \\
\text { BT }\end{array}$ & \\
\hline NTT & Ngada & $\begin{array}{l}1975- \\
1978\end{array}$ & $\begin{array}{l}10^{\circ} 9^{\prime} \\
\text { LS : } \\
123^{\circ} 36^{\prime} \\
\text { BT }\end{array}$ & 5.117 \\
\hline
\end{tabular}

\subsection{Jenis panel sel surya}

Panel surya mengubah energi matahari menjadi energi listrik. Sel surya terdiri dari photovoltaic yang menghasilkan listrik dari intensitas cahaya. Saat intensitas cahaya berkurang (berawan, hujan, dan mendung) arus listrik yang dihasilkan juga akan berkurang. Panel surya akan menghasilkan daya yang berbeda tergantung dari ukurannya. Contohnya ukuran $\mathrm{a} \mathrm{cm} \times \mathrm{b} \mathrm{cm}$ menghasilkan listrik Direct Current (DC) sebesar $x$ Watt per hour/jam. [6]

\subsubsection{Polikristal (Poly-crystalline)}

Polikristal merupakan panel surya yang memiliki susunan kristal acak. Polikristal memerlukan luas permukaan yang lebih besar dibandingkan dengan jenis monokristal untuk menghasilkan daya listrik yang sama, akan tetapi dapat menghasilkan listrik pada saat mendung. [6]

\subsubsection{Monokristal (Mono-crystalline)}

Monokristal merupakan panel yang paling efisien, karena panel monokristal menghasilkan listrik persatuan luas yang paling tinggi. Panel monokristal mempunyai kelemahan jika cuaca kurang cerah (berawan, mendung, atau teduh) efisiensinya akan turun drastis. [6]

\subsection{Potensi Daya}

Potensi daya adalah suatu kekuatan, kemampuan atau daya yang mampu dikembangkan lebih baik atau lebih besar lagi. Pada penelitian kali ini menggunakan rumus daya (3)

$$
\mathrm{P}=\mathrm{V} \times \mathrm{I}
$$

\subsection{Alat Ukur}

Alat Ukur yang digunakan dalam penelitian ini adalah alat ukur arus dan tegangan atau bisa disebut AVO meter.AVO meter sering di sebut dengan Multimeter atau multitester. 
AVO meter adalah alat untuk mengukur arus, tegangan, baik itu arus AC mapun DC.

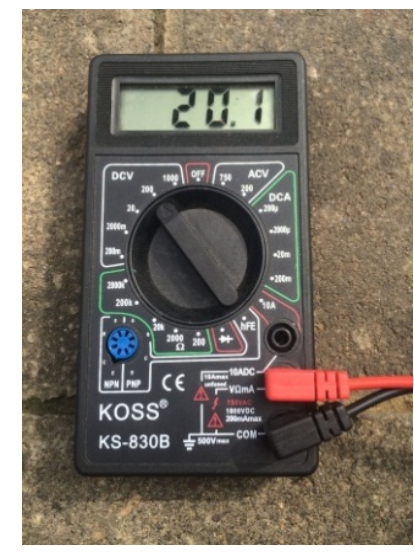

Gambar 2. AVO meter (Ampere dan Volt Meter)

\section{METODE PENELITIAN}

Data yang diperlukan pada penelitian ini adalah data primer dan data sekunder. Data primer yang digunakan adalah pengukuran pada arus dan tegangan dari panel

surya, data hasil pengukuran pada atap Bale Sari. Data sekunder merupakan data yang diperoleh dari referensi buku, jurnal ilmiah, tugas akhir, dan hasil pencarian di internet.

Proses perhitungan untuk mendapatkan nilai dari arus dan tegangan dilakukan mulai dari pukul 07.00-17.00 Wita, dan dilakukan saat cuaca sangat cerah. Pengukuran dilakukan dengan menggunakan alat ukur AVO meter.

\section{HASIL DAN PEMBAHASAN \\ 4.1. Menghitung Luas Atap}

Rumah berasitektur Bali yang menjadi studi kasus bertempat di banjar Tegeh, Desa Dalung, Kabupaten Badung. Salah satu bangunan berasitektur bali adalah Bale Sari. Bale Sari yang digunakan untuk penelitian ini mempunyai panjang atap $6,40 \mathrm{~m}$ dan lebar atapnya $5,10 \mathrm{~m}$, yang ditunjukkan Gambar 3 , sedangkan tinggi atapnya $2,75 \mathrm{~m}$ dan alas atasnya $2,20 \mathrm{~m}$.

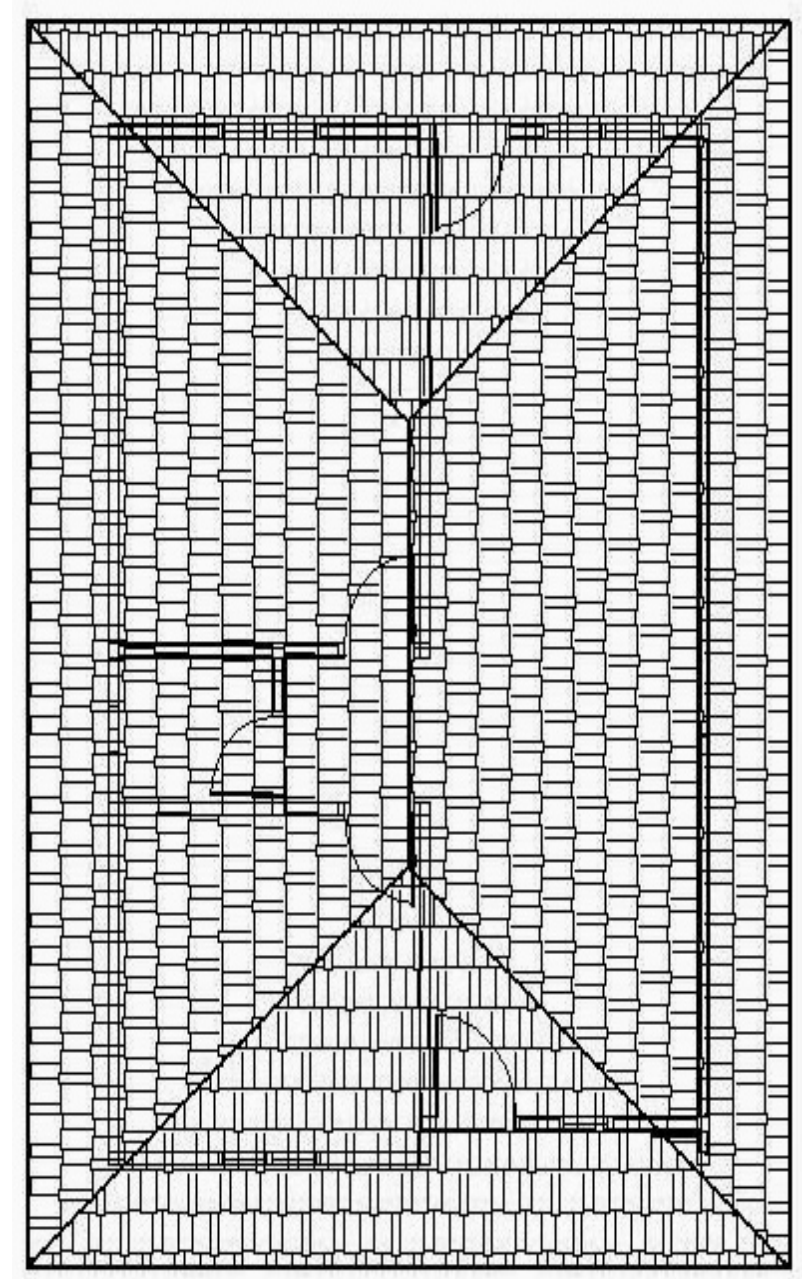

Gambar 3. Gambar atapBale Sari

Bale sari mempunyai dua sisi atap yang berbeda, sisi bagian barat dan timur berbentuk segitiga dapat dilihat

pada Gambar 4. Bagian utara dan selatan berbentuk trapesium dapat dilihat pada Gambar 5.

Setelah diketahui luas atap tersebut, pertama yang dapat dilakukan adalah membagi bidang tersebut menjadi 2 bagian, yang dibagi menjadi bidang segitiga dan bidang trapesium. 


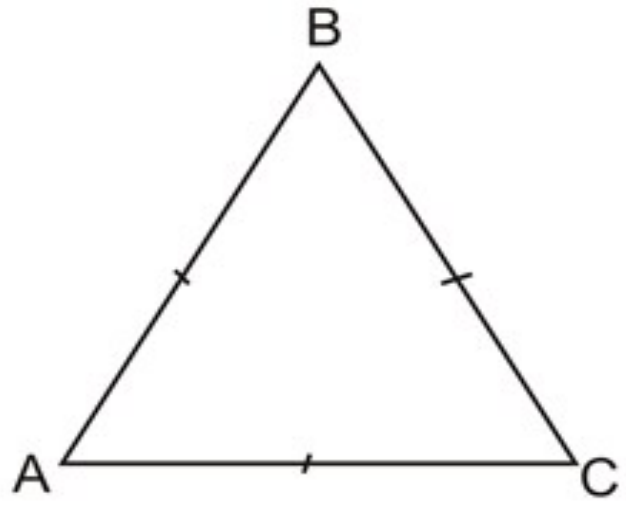

Gambar 4. Gambar bangun segitiga (a)

A) Menghitung luas segitiga

$$
\text { Luas } \begin{aligned}
\Delta & =\frac{1}{2} \times(\mathrm{axt}) \\
& =\frac{1}{2} \times(5,10 \mathrm{~m} \times 2,75 \mathrm{~m}) \\
& =7.01 \mathrm{~m}^{2}
\end{aligned}
$$

Luas total $=7.01 \mathrm{~m}^{2}$

Jadi luas segitiga persisinya, baik sisi barat dan timur adalah $7.01 \mathrm{~m}^{2}$.

Dan untuk luas total segitiga $=7.01^{\mathrm{m} 2} \times 2=$ $14.02 \mathrm{~m}^{2}$

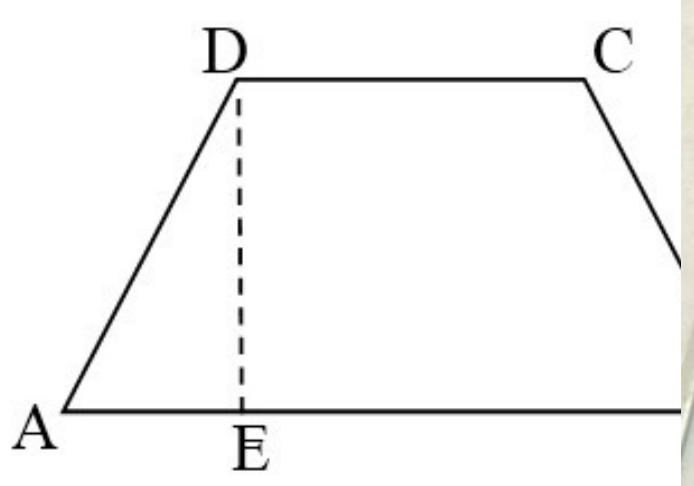

Gambar 5. Gambar bangun trapesium (b)

B) Menghitung luas trapesium

$$
\begin{aligned}
\text { Luas trapesium } & =\frac{\text { jumlah sisi } \mathrm{x} \text { tinggi }}{2} \\
& =\frac{(A B+C D) \times t}{2} \\
& =\frac{(6,40 \mathrm{~m}+2,20 \mathrm{~m}) \times 2,75 \mathrm{~m}}{2} \\
& =11,82 \mathrm{~m}^{2}
\end{aligned}
$$

Jadi luas trapesium persisinya, baik pada bagian utara maupun selatan adalah 11,82 $\mathrm{m}^{2}$ dan luas total trapesium adalah $=11,82$ $\mathrm{m}^{2} \times 2=23,65 \mathrm{~m}^{2}$

\subsection{Spesifikasi Panel Surya dan Luas Panel} Surya

Panel surya, ditunjukkan pada Gambar 6, yang akan digunakan untuk pengukuran pada rumah dengan pola atap berasitektur Bali mempunyai daya maksimal sebesar 10 Watt dengan spesifikasi panel surya sebagai berikut.

1. Maximal Power (Pmax) $10 \mathrm{~W}$

2. Maximum Power Voltage (Vmp) $17.2 \mathrm{~V}$

3. Maximum Power Current (Imp) $0.58 \mathrm{~A}$

4. Open Circuit Voltage (Voc) $20.64 \mathrm{~V}$

5. Short Ciruit Current Isc $0.65 \mathrm{~A}$

6. Nominal Operating Cell Temp (NOCT) $45 \pm 2^{\circ} \mathrm{C}$

7. Maximum System Voltage $1000 \mathrm{~V}$

8. Maximum Series Fuse $16 \mathrm{~A}$

9. Dimension $415 \mathrm{~mm} \times 245 \mathrm{~mm}$

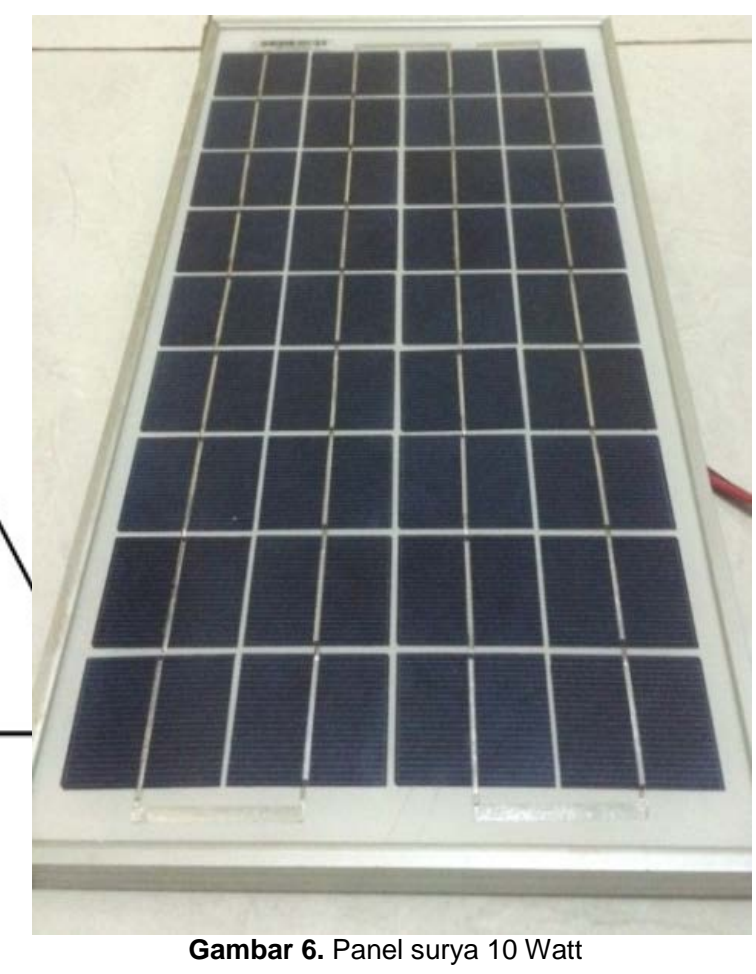

Panel surya yang akan digunakan mempunyai dimensi sebesar $415 \mathrm{~mm} \times 245$ $\mathrm{mm}=101.675 \mathrm{~mm}^{2}$.

\subsection{Mencari Jumlah Panel Surya Yang Akan Di Pasang}

Setelah diketahui luas atap rumah berbasis arsitektur bali dan luas dimensi dari panel surya, diaplikasikan ke dalam Gambar yang menggunakan buku Gambar milimeter block. 


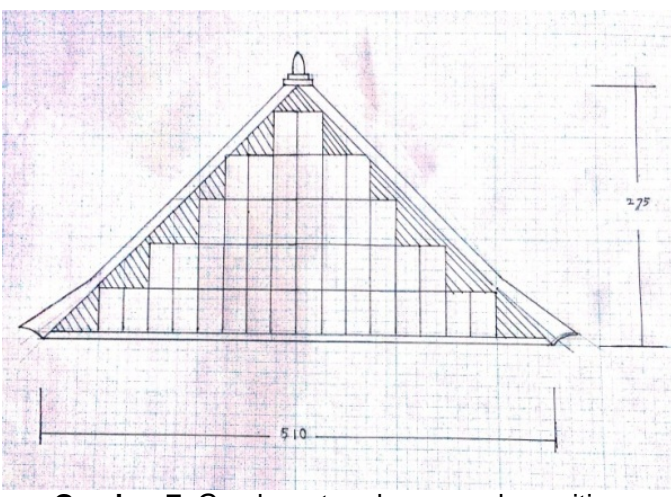

Gambar 7. Gambar atap dengan pola segitiga

Dari data yang diambil pada tempat penelitian, dan disesuaikan dengan luas atap dan dimensi panel surya, jumlah panel yang digunakan untuk pola atap berbentuk segitiga berjumlah 44 buah panel dan dapat dilihat pada Gambar 7.

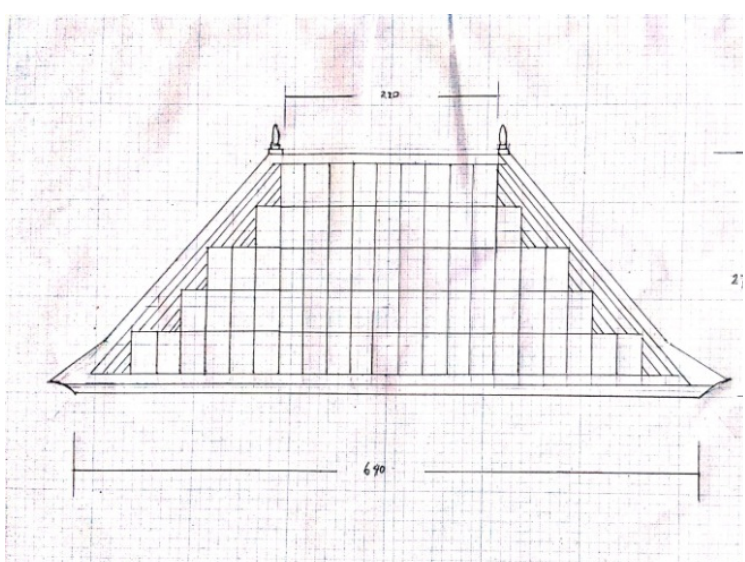

Gambar 8. Gambar atap dengan pola trapesium

Jumlah panel surya yang akan digunakan untuk pola atap rumah berbentuk trapesium adalah 73 buah, dapat dilihat pada Gambar 8 .

\subsection{Hasil Pengukuran Pada Panel Barat}

Setelah diketahui pada atap sisi barat berpola segitiga maka jumlah panel surya yang digunakan berjumlah 44 panel. Hasil pengukuran panel surya pada sisi bagian barat, dapat dilihat pada Tabel 2 . bagian barat

Tabel 2. Hasil pengukuran pada sisi atap

\begin{tabular}{|c|c|c|c|c|l|}
\hline \multirow{2}{*}{ No } & \multirow{2}{*}{ Pukul } & \multicolumn{3}{|c|}{ Panel Barat } & \multirow{2}{*}{ Cuaca } \\
\cline { 3 - 5 } & $\mathrm{V}$ & $\mathrm{I}$ & $\mathrm{P}$ & \\
\hline 1 & 8.00 & 20,2 & 10,12 & 204,42 & Cerah \\
\hline 2 & 9.00 & 20 & 12,32 & 246,4 & Cerah \\
\hline
\end{tabular}

\begin{tabular}{|c|c|c|c|c|l|}
\hline 3 & 10.00 & 20,1 & 14,96 & 300,69 & Cerah \\
\hline 4 & 11.00 & 20,2 & 18,04 & 364,41 & Cerah \\
\hline 5 & 12.00 & 20,2 & 24,2 & 488,84 & Cerah \\
\hline 6 & 13.00 & 19,2 & 25,52 & 515,50 & Cerah \\
\hline 7 & 14.00 & 20 & 27,28 & 545,6 & Cerah \\
\hline 8 & 15.00 & 20,8 & 19,8 & 411,84 & Cerah \\
\hline 9 & 16.00 & 20 & 18,04 & 360,8 & Cerah \\
\hline 10 & 17.00 & 20,1 & 16,28 & 327,23 & Cerah \\
\hline \multicolumn{7}{|c|}{ Rata-rata daya yang di dapat } & 376,57 Watt \\
\hline
\end{tabular}

Dari hasil perhitungan didapat daya ratarata panel surya terpasang pada atap rumah berbasis arsitektur Bali pada sisi barat sebesar 376,57 Watt. Jumlah panel surya yang digunakan adalah 44 buah.

\subsection{Hasil Pengukuran Pada Panel Timur}

Setelah diketahui pada atap sisi timur berpola segitiga maka jumlah panel surya yang digunakan berjumlah 44 panel.

Hasil pengukuran pada sisi bagian timur dapat dilihat pada Tabel 3.

\begin{tabular}{|c|c|c|c|c|c|}
\hline \multirow{2}{*}{ No } & \multirow{2}{*}{ Pukul } & \multicolumn{3}{|c|}{ Panel timur } & \multirow{2}{*}{ Cuaca } \\
\hline & & V & I & $\mathrm{P}$ & \\
\hline 1 & 8.00 & 20,3 & 22,44 & 455,53 & Cerah \\
\hline 2 & 9.00 & 20,3 & 30,8 & 625,24 & Cerah \\
\hline 3 & 10.00 & 20,5 & 27,72 & 568,26 & Cerah \\
\hline 4 & 11.00 & 20,2 & 23,32 & 471,06 & Cerah \\
\hline 5 & 12.00 & 20,1 & 27,28 & 548,33 & Cerah \\
\hline 6 & 13.00 & 20 & 20,68 & 413,6 & Cerah \\
\hline 7 & 14.00 & 19,9 & 12,32 & 245,17 & Cerah \\
\hline 8 & 15.00 & 19,5 & 7,04 & 137,28 & Cerah \\
\hline 9 & 16.00 & 19,1 & 7,04 & 134,46 & Cerah \\
\hline
\end{tabular}




\begin{tabular}{|l|c|c|c|c|c|}
\hline 10 & 17.00 & 18,6 & 4,4 & 81,84 & Cerah \\
\hline \multicolumn{3}{|c|}{ Rata-rata daya yang di dapat } & \multicolumn{2}{|c|}{368,07 Watt } \\
\hline
\end{tabular}

Dari hasil prhitungan didapat daya rata-rata panel surya terpasang pada atap rumah arsitektur Bali pada sisi timur sebesar 368,07 Watt. Jumlah panel surya yang digunakan adalah 44 buah.

\subsection{Hasil Pengukuran Pada Panel Utara}

Setelah diketahui pada atap sisi utara berpola segitiga maka jumlah panel surya dapat dihitung, yaitu 73 panel. Hasil dari pengukuran panel surya pada sisi bagian utara, ditunjukkan pada tabel 4. Hasil pengukuran pada sisi atap bagian utara.

Tabel 4. Hasil pengukuran pada sisi atap bagian utara

\begin{tabular}{|c|c|c|c|c|l|}
\hline \multirow{2}{*}{ No } & \multirow{2}{*}{ Pukul } & \multicolumn{3}{|c|}{ Panel utara } & \multirow{2}{*}{ Cuaca } \\
\cline { 3 - 5 } & & $V$ & $I$ & $P$ & \\
\hline 1 & 8.00 & 20,3 & 21,17 & 429,75 & Cerah \\
\hline 2 & 9.00 & 20 & 24,82 & 496,4 & Cerah \\
\hline 3 & 10.00 & 20,2 & 35,77 & 722,55 & Cerah \\
\hline 4 & 11.00 & 20,3 & 40,15 & 815,04 & Cerah \\
\hline 5 & 12.00 & 20,1 & 40,15 & 807,01 & Cerah \\
\hline 6 & 13.00 & 19,9 & 32,12 & 639,18 & Cerah \\
\hline 7 & 14.00 & 19,2 & 25,55 & 490,56 & Cerah \\
\hline 8 & 15.00 & 19,9 & 14,6 & 290,54 & Cerah \\
\hline 9 & 16.00 & 19,7 & 18,25 & 359,52 & Cerah \\
\hline 10 & 17.00 & 19,1 & 9,49 & 181,26 & Cerah \\
\hline Rata-rata daya yang di dapat & 523,18 Watt \\
\hline
\end{tabular}

Dari hasil perhitungan didapat daya ratarata panel surya terpasang pada atap rumah berbasis arsitektur Bali pada sisi utara sebesar 523,18 Watt. Jumlah panel surya yang digunakan adalah 73 buah.

\subsection{Hasil Pengukuran Pada Panel Selatan}

Setelah diketahui pada atap sisi selatan berpola segitiga maka jumlah panel surya yang digunakan berjumlah 73 panel. Hasil dari pengukuran panel surya pada sisi bagian selatan, dapat dilihat pada Tabel 5 .
Hasil perhitungan menunjukkan bahwa daya rata-rata yang didapat solar cell terpasang pada atap rumah berbasis arsitektur Bali pada sisi selatan sebesar 667,67 Watt, dengan jumlah 73 buah panel.

Tabel 5. Hasil pengukuran pada sisi bagian selatan

\begin{tabular}{|c|c|c|c|c|l|}
\hline \multirow{2}{*}{ No } & \multirow{2}{*}{ Pukul } & \multicolumn{3}{|c|}{ Panel Selatan } & \multirow{2}{*}{ Cuaca } \\
\cline { 3 - 5 } & & $\mathrm{V}$ & $\mathrm{I}$ & $\mathrm{P}$ & \\
\hline 1 & 8.00 & 20,5 & 35,77 & 733,28 & Cerah \\
\hline 2 & 9.00 & 20,1 & 36,5 & 733,65 & Cerah \\
\hline 3 & 10.00 & 20,1 & 34,31 & 689,63 & Cerah \\
\hline 4 & 11.00 & 19,7 & 24,09 & 474,57 & Cerah \\
\hline 5 & 12.00 & 20,2 & 45,26 & 914,25 & Cerah \\
\hline 6 & 13.00 & 20 & 45,26 & 905,2 & Cerah \\
\hline 7 & 14.00 & 20,6 & 35,04 & 721,82 & Cerah \\
\hline 8 & 15.00 & 20,8 & 33,58 & 698,46 & Cerah \\
\hline 9 & 16.00 & 19,9 & 21,9 & 435,81 & Cerah \\
\hline 10 & 17.00 & 19,5 & 18,98 & 370,11 & Cerah \\
\hline \multicolumn{2}{|r|}{ Rata-rata daya yang di dapat } & 667,67 Watt \\
\hline
\end{tabular}

\subsection{Hasil Analisis Potesi Daya Total}

Hasil analisis potensi daya total yang didapat panel surya terpasang, ditunjukkan pada Tabel 6.

Tabel 6. Hasil analisis potensi daya total

\begin{tabular}{|c|c|}
\hline Posisi Panel & Total daya yang di dapat \\
\hline Panel Barat & $376,57 \mathrm{~W}$ \\
\hline Panel Timur & $368,07 \mathrm{~W}$ \\
\hline Panel Utara & $523,18 \mathrm{~W}$ \\
\hline Panel Selatan & $667,67 \mathrm{~W}$ \\
\hline Total Daya Keseluruhan & $1.935,49 \mathrm{~W}$ \\
\hline
\end{tabular}

Jumlah panel keseluruhan yang digunakan untuk penelitian ini dapat dilihat pada Tabel 7 .

Tabel 7. Hasil analisis jumlah panel yang diperlukan

\begin{tabular}{|c|c|}
\hline Posisi Panel & Jumlah Panel \\
\hline Panel Barat & 44 Panel \\
\hline Panel Timur & 44 Panel \\
\hline Panel Utara & 73 Panel \\
\hline
\end{tabular}




\begin{tabular}{|c|c|}
\hline Panel Selatan & 73 Panel \\
\hline Jumlah Panel Keseluruhan & 234 Panel \\
\hline
\end{tabular}

Tabel 7 menunjukkan bahwa daya maksimal total yang didapat dari panel surya terpasang pada atap rumah arsitektur Bali, sebesar 1.935,49 Watt. Daya terbesar terdapat pada pengukuran panel sisi bagian Selatan dengan total daya yang didapat 667,67 Watt, dan jumlah panel seluruhnya yang digunakan adalah 234 buah panel. Dengan komposisi masing-masing sisi mempunyai jumlah yang berbeda, untuk panel Barat dan Timur dengan sisi segitiga membutuhkan total 44 panel surya untuk masing-masing bagian, sedangkan sisi Utara dan Selatan, sisinya yang berbentuk trapesium membutuhkan 73 panel surya untuk masing-masing bagian.

\section{KESIMPULAN}

Potensi daya maksimal yang didapatkan pada penelitian ini adalah 1935,49 watt dengan jumlah seluruh panel surya 234 buah. Komposisi jumlah panel pada masing-masing sisi adalah44 buah pada bagian Barat dan Timur, sedangkan pada bagian Utara dan Selatan membutuhkan 73 panel surya untuk masing-masing sisinya.

\section{DAFTAR PUSTAKA}

[1] A. I Nyoman,B. Ika I Wayan danS. Negara I Nengah, Peranan Garis Dalam Konsep Minimalis Desain Interior Rumah Tinggal. Denpasar, Indonesia : Fakultas Seni Rupa Dan Desain Institut Seni Indonesia,2012.

[2] Y. Subekti, S. Gede, dan H. Retno, "Pengaruh Perubahan Intensitas Matahari Terhadap Daya Keluaran Panel Surya", Jurnal Pengabdian LPPM Untag Surabaya, Vol. 01, No. 02, Nov. 2015.

[3] Ima Maysha, Bambang Trisno, dan Hasbullah, "Pemanfaatan Tenaga Surya Menggunakan Rancangan Panel Surya Berbasis Transistor 2n3055 dan Thermoelectric Cooler", Elektro FPTK UPI, ELECTRANS, vol.12.
[4] Suriadi dan Mahdi Syukri, "Perencanaan Pembangkit Listrik Tenaga Surya (PLTS) Terpadu Menggunakan Software PVSYST Pada Komplek Perumahan di Banda Aceh," Jurusan Teknik Elektro, Universitas Syiah Kuala, Jurnal Rekayasa Elektrika Vol. 9, No. 2, 2010.

[5] Badan Pengkajian dan Penerapan Teknologi. Strategi Penyediaan Listrik Nasional dalam Rangka Mengantisipasi Pemanfaatan PLTU Batubara Skala Kecil, PLTN, dan Pembangkit Energi Terbarukan. Jakarta, 2005.

[6] M. Rif'an, Sholeh HP, Mahfudz Shidiq, Rudy Yuwono, Hadi Suyono dan Fitriana S. Optimasi Pemanfaatan Energi Listrik Tenaga Matahari di Jurusan Teknik Elektro Universitas Brawijaya. 